\title{
Introduction: The Internet as an Ethical Challenge for Religions
}

\section{Agenda:}

1. Religions and ICT

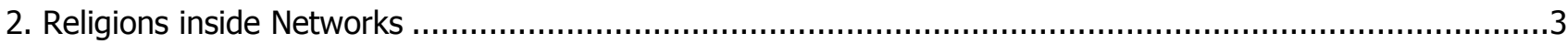

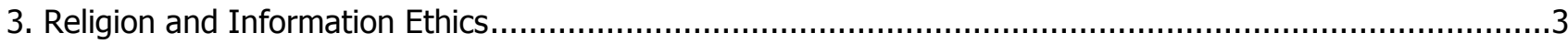

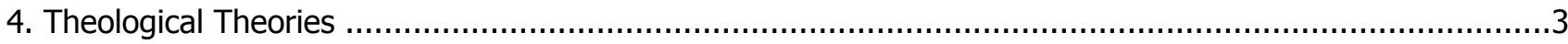

\section{Authors:}

Dr. Chibueze C. Udeani

- Institute for Caritative Science, Catholic-theological Private University, Linz, Austria, Bethlehemstr. 20, 4020 Linz, Austria

- 愐 0043/(0)732/784293-4187, $ه$ c.udeani@ktu-linz.ac.at, 몽 http://www.ktu-linz.ac.at.icw

Prof. Dr. Rafael Capurro:

- Hochschule der Medien (HdM), Wolframstr. 32, 70191 Stuttgart, Germany

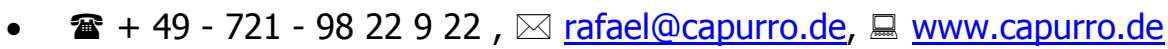

- Relevant publications:

- Leben im Informationszeitalter. Berlin: Akademie Verlag 1995, 134 p.

- Ethik im Netz. Stuttgart: Franz Steiner Verlag 2003, 278 p.

Dr. Johannes J. Frühbauer

- Universität Augsburg, Katholisch-Theologische Fakultät, Christliche Sozialethik, Universitätsstrasse 10, D-86135 Augsburg

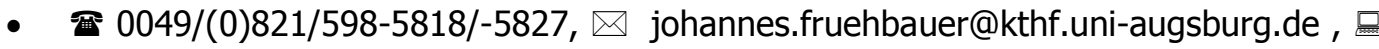
www.fruehbauer.de 
Religions are not only communities of faith but also of communication. Religious communication takes place vertically between human beings and a transcendent holy entity. It also occurs horizontally among individuals and groups. This is the reason why religions cannot remain unaffected by the development and the future directions of the global digital network.

Communication does not take place only within a single religious community but also among several religious groups and between them and the secular world. Functional, structural, communicational and occasionally ethical commonalities between religions cannot hide the fact that there are lots of deep differences as well as particular interests. This is the reason why these forms of religious communication are characterized by all kinds of tensions and conflicts. Mistrust, fear of living under constant threat, a hermeneutics of suspicion, and strategies of domination are common sources of potential conflicts in the present time.

In view of this situation, religions experience the challenge of giving ethical answers to pressing questions particularly in the field of information and communication technology that is at the same time an important instrument for religious communication:

- Do religions conceive ICT inventions and innovations as threatening or as beneficial?

- Do they see the opportunities offered by ICT as a possible avenue to communicate their contents and values?

- Or do they, on the contrary, see ICT as a threat arising from the free access to information that allows alternative groups to offer different kinds of meanings to texts and events?

- Which kinds of relations are being addressed by religions, in general, towards the media?

- Which principles of information ethics are being applied or betrayed?

- Which kinds of political, economic or ideological movements can become a threat for these principles being misused or undermined?

- How do religious institutions (such as churches, local communities, charity organizations, religious orders, religious groups, religious media institutions, etc.) use and evaluate ICT?
- To what extent can religious groupings contribute to the international ethical debate regarding ICT and its application?

The issue's conception had the following structure:

\section{Religions and ICT}

a. Views of religions and their theologies on IT and the internet

b. Impact of ICT on religious power structures (centralization vs. decentralization, vertical hierarchies vs. horizontal networking)

\section{Religions inside Networks}

c. Basic questions concerning the presence of religions on the internet

d. Theological discourses on the internet

e. Presence and presentation of religious communities on the internet

f. Religious and theological conflicts on the internet

g. Comparative analyses of the presence and use of the internet by religions and religious communities

h. Religious offers on the internet

i. Digital networks as a missionary strategy

j. Internet as a medium for political presence and the influence of religions

$k$. The critique of religion on the internet

l. ICT as platform for antireligious perspectives/activities

m. Religious contributions to ICT for Development (ICT4D)

\section{Religion and Information Ethics}

n. Information ethics theories about the presence of religions in the digital network

o. Theological information ethics

p. Changes of religious-based ethics as a consequence to the internet

\section{Theological Theories}

q. Religious paradigms on the digital network

$r$. The internet as religion or as an ersatz religion 
s. The internet as a place for religious community

t. Apocalyptic potentiality of the digital network / Apocalypse on the internet

u. Theological enlightenment through the internet

Contributions to some of these topics have already been published in journals and other media for instance "Concilium" (Vol. 41, March 2005): "Cyber Space - Cyber Ethics - Cyber Theology" (Erik Borgman, Stephan van Erp, Hille Haker, Eds.) as well as in the special issue of the Journal of ComputerMediated Communication (Vol. 12, issue 2, 2007): "Cross-cultural Perspectives on Religion and Computer-Mediated Communication" (Charles Ess, Ed.). We want to highlight also the Online- Heidelberg Journal of Religions on the Internet.

For this IRIE issue authors were invited to send an article from the perspective of one specific religion among them, the abrahamitic-prophetic in addition to Asian sage-oriented religions, 'traditional religions' such as African or Western ones, and other indigenous religious (excluding sects).

Takanori Tamura and Daiyu Tamura analyze the structure of unsuccessful chats over the internet within the context of Japanese religions. In Japan, chats about religion rarely succeed. This is due, according to the authors, not only to the lack of social cues and anonymity but also because there is a power balance between two groups, one with a positive attitude towards religion and the other with a negative attitude.

Richard Cohen examines Plato's two complaints in the Phaedrus about the new technology of writing in relation to Jewish rabbinic exegetical tradition and to Immanuel Kant's positive claims for text based religions in Religion within the Limits of Reason Alone.

Richard Shields asks for how religions formulate ethical responses to the challenges arising from information-communication technology. He focusses on official teaching of the Catholic Church which attempts to provide a consistent and universal perspective for making moral judgments about these technologies and the communications media they enable and sustain. The author examines how ethics and religion come together in Catholic teaching, he discusses certain problems arising from that approach, and concludes with suggestions for a future religious ethics of ICT.
Thomas Zeilinger deals with the way the big churches in Germany traditionally address ethical issues by discursive memoranda and pastoral letters. The article explores the possibilities of a complementary approach by symbolic presentation.

Patheneni Sivaswaroop presents results of a sample study on how Hindus are using the Internet for religious purposes comparing their online and offline religious activities. According to Sivaswaroop some $74 \%$ of the people sampled pray daily, but only $16 \%$ go daily to a local temple. In Hinduism going to the temple is secondary as each Hindu house is has generally a Pooja Room/Corner. They are equally divided on whether the internet increases religious tolerance or hatred.

Ian Kenway explores the limitations and distortions of religious discussion on the internet within the wider context of those ethical challenges posed by controversy and debate in cyberspace. It attempts to establish a series of critical connections between the emergence of polemical forms of 'feuilletonism' in the area of religious comment and the characteristic weightlessness of language which has become detached from the body, despite the latter's extension and intensification in the concrete social realisations found in specific faith communities.

Christoph Stückelberger analyzes chances of ICT for religious ethics such as access to information and argumentation; broader access to different traditions around the globe and to history of the own tradition; deeper understanding of other religious and non religious ethics through easier access and exchange. He also deals with the challenges of ICT for religious ethics such as relativism, pragmatism, syncretism, and opportunism.

We, the Guest Editors, are glad to contribute with this IRIE issue to this important international and intercultural debate on religion $\&$ the internet. 